\title{
INTEGRASI ILMU AGAMA DAN SAINS: STUDI PENULISAN SKRIPSI DI UIN SYARIF HIDAYATULLAH JAKARTA
}

\author{
Saifudin \\ Dosen FST UIN Syarif Hidayatullah Jakarta \\ E-Mail: dinlai75@uinjkt.ac.id
}

\begin{abstract}
Abstrak: Integrasi ilmu di UIN Syarif Hidayatullah Jakarta (UIN Jakarta) adalah mandat utama transformasi perubahan status IAIN menjadi UIN. Pemikiran dan gagasan ini menegaskan bahwa secara filosofis antara (ilmu) agama atau sains tidak ada pertentangan. Keduanya berwatak Islami karena keduanya bersumber dari Allah SWT, baik berupa wahyu maupun alam semesta. Oleh karena itu, sains tidak bebas nilai dan tidak dikhotimis. Kendati demkian, hasil penelitian ini menunjukkan bahwa gagasan integrasi ilmu agama dan sains di UIN Jakarta belum terimplmentasi pada regulasi, metode, petunjuk pelaksanaan (juklak) serta petunjuk teknis (juknis) dengan konsepsi atau narasi yang disampaikan UIN Jakarta. Sebanyak 45 skripsi di bidang sains yang dijadikan sample penelitian ini tidak ditemukan pemikiran atau model integrasi ilmu agama dan sains. Integrasi di UIN Jakarta hanya tampak pada kebijakannya, yaitu para Surat Keputusan Rektor. Masalah pokok yang dikaji dalam penelitian adalah bagaimana model, rupa atau bentuk implementasi integrasi ilmu agama dan sains dalam penulisan karya skripsi di UIN Jakarta.
\end{abstract}

Kata Kunci: integrasi, ilmu agama, sains, implementasi.

\section{PENDAHULUAN}

Tak diragukan lagi bahwa satu alasan utama transformasi Institut Agama Islam Negeri (IAIN) Syarif Hidayatullah Jakarta menjadi Universitas Islam Negeri (UIN) Syarif Hidayatullah Jakarta (UIN Jakarta) adalah melakukan integrasi keilmuan. ${ }^{1}$ Usaha tersebut dinilai sangat penting dan dibutuhkan oleh institusi pendidikan tinggi Islam karena secara filosofis ilmu dalam Islam adalah satu kesatuan (integral). ${ }^{2}$

1 Integrasi ilmu adalah ikhtiar menyatukan aspek epistemologi antara satu bidang ilmu dengan bidang ilmu lainnya, sehingga satu ilmu dengan ilmu yang lain tidak saling bertentangan dan menegasikan, serta tidak dikhotomis. Lihat Abuddin Nata, dkk, Integrasi Ilmu Agama dan Ilmu Agama, (Jakarta: UIN Jakarta Press, 2003). Baca pula Sudarnoto Abdul Hakim dkk, Integrasi Keilmuan UIN Syarif Hidayatullah Jakarta Menuju Universitas Riset, (Jakarta: PPJM dan UIN Jakarta Press, 2006). Tentang alih status IAIN Syarif Hidayatullah Jakarta menjadi UIN dapat dibaca pada Keputusan Presiden Nomor 31 Tahun 2002.
Transformasi institusional tersebut tentu dapat dipahami sebagai dinamika sosial politik yang seharusnya. Alasannya jelas, sebagai Perguruan Tinggi Keagamaan Islam Negeri (PTKIN) secara legal-formal UIN Jakarta eksistensinya tidak berbeda dengan Perguruan Tinggi Umum (PTU) lainnya. Bahkan, UIN Jakarta dan PTKIN serta PTKI pada umumnya punya peran lebih dari PTU. Karena itu, sebagai bagian dari sub-sistem Pendidikan Nasional, UIN Jakarta juga terikat dengan komitmen mengemban misi utama perguruan tinggi, yakni Tridharma Perguruan Tinggi dalam pengertian seluas-luasnya. Lebih dari itu, dalam rangka memegang kuat komitmen tersebut UIN Jakarta mewarnainya dengan citra diri yang menonjolkan atmosfir akademiknya dengan kehidupan ruh agama.

Paradigma Integrasi-Interkoneksi, (Yogyakarta: Suka Press, 2007). 
Untuk meneguhkan dan mengimplementasikan hal tersebut, sejak berubah menjadi univeritas, UIN Jakarta membuka dan mengembangkan ilmuilmu baru, program studi (prodi) atau jurusan dan fakultas baru.

Beberapa prodi dan fakultas baru itu, antara lain, Biologi, Fisika, Kimia, Teknik Informatika dan Agribisnis (Fakultas Sains dan Teknologi), Ekonomi dan Manajemen (Fakultas Ekonomi dan Bisnis), Pendidikan Dokter, Farmasi, Keperawatan, dan Kesehatan Masyarakat (Fakultas Kedokteran dan Ilmu Kesehatan), dan Ilmu Poltik, Sosiologi, dan lain-lainnya.

Langkah tersebut menandai dan merupakan lompatan besar bagi UIN menjadi perguruan tinggi Islam modern dengan tetap memegang teguh pada nilainilai keislaman dan keindonesiaan. Atau dalam bahasa lain, ijtihad akademik IAIN menjadi UIN merupakan tonggak baru dalam sejarah pendidikan Islam modern di Indonesia. ${ }^{3}$

Dalam konteks kemodernan, integrasi ilmu agama dan sains merupakan keniscayaan. Di era modern sekarang ini tidak ada sisi kehdupan manusia yang alpa dari sains. Secara sosiologis, manusia telah terperangkap dalam arus globalisasi. Hal tersebut ditandai dengan pola dan gaya hidup masyarakat sekuler dan agamis yang saat ini sebagian hidupnya telah dikendalikan oleh sistem atau logika sains. Ini artinya sains betul-betul telah menjadi nafas kehidupan manusia modern. ${ }^{4}$ Bahkan saat ini terdapat kecenderungan agama diacuhkan oleh sebagian manusia. ${ }^{5}$

Namun, bagaimanapun agama bagi orang beriman merupakan jantung terpenting dalam hidupnya. Tanpa

3 Fuad Jabali dan Jamhari, IAIN dan Modernisasi Islam di Indonesia, (Jakarta: Logos, 2002).

4 Abdussalam, Sains dan dunia Islam, terj. Baiquni, (Bandung: Pustaka, 1983).

5 Ahmed, Akbar S. Islam, 1994. Globalization and Post Modernism and Islam (London: Routledge). agama, semua aktivitas orang beriman tidak bermakna. Ini artinya ilmu agama merupakan dasar, norma, dan pedoman, serta nilai bagi seseorang melakukan aktivitas kehidupan sehari-harinya.

Dengan demikian antara sains dan agama tidak bisa dipisahkan, apalagi dipertentangkan. Hal ini dapat dimaklumi, karena secara epistemologis keduanya bersumber dari Dzat Yang Satu, yaitu Allah SWT. Di sinilah posisi pentingnya mengintegrasikan ilmu agama dan sains dalam kehidupan. ${ }^{6}$ Penyatuan (ilmu) agama dan sains merupakan bentuk peneguhan tauhid seseorang dalam kehidupan social bermasyarakat dan buah dari keimanan seseorang. ${ }^{7}$

Sebagaimana diketahui bahwa transformasi UIN Jakarta telah berlangsung hampir dua dasawarsa. Dengan demikian gagasan dan proses implementasi integrasi ilmu agama dan sains diUINJakarta perlu dikajilebihlanjut fakta dan buktinya. Apakah UIN Jakarta sudah mengimplementasikan integrasi? Dan bagaimana bentuk atau rupa integrasi tersebut diimplementasikan?

Berdasarkan rumusan masalah di atas, penelitian ini bertujuan untuk mendiskripsikan dan menganalisis pelaksanaan integrasi ilmu agama dan sains serta sejauh mana integrasi ilmu agama dan sains di UIN Jakarta telah diimplementasikan dalam ranah akademik, misalnya dalam penulisan karya ilmiah skripsi.

Skripsi dijadikan sample penelitian ini karena ia merupakn satu dari sekian out put pendidikan tinggi. Selain itu pula, dari skripsi akan terbaca dan dapat diketahui kebijakan, manajerial, dan program akademik tentang integrasi.

6 M. Amin Abdullah, Falsafah Kalam di Era Postmodernisme, (Pustaka Pelajar: Yogyakarta, 1995), cet. I,

7 Isma'il Raji al-Faruqi, Tawhid: Its Implications for Thought and Life, terj. Rahmani Astuti, Tauhid, ( Bandung: PUSTAKA, 1982). 
Dari penelusuran pelbagai sumber dan informasi, penulis belum menemukan kajian atau penelitian tentang integrasi ilmu agama dan sains dalam penulisan skripsi di UIN Jakarta.

Beberapa penelitian terkait, misalnya artikel berjudul "Integrasi Keilmuan dalam Pengembangan Kurikulum di UIN Se-Indonesia:Evaluasi Penerapan Integrasi Keilmuan UIN dalam Kurikulum dan Proses Pembelajaran" oleh Nurlena Rifai, Fauzan, Wahdi Sayuti, Bahrissalim. Artikel dalam jurnal TARBIYA Vol. I, No.1, Juni 2014 ini mengkaji implementasi gagasan integrasi ilmu pada level kebijakan dan kurikulum. Kesimpulan tulisan antara lain adalah bahwa integrasi yang dilakukan oleh UIN dan beberapa UIN lain baru pada tahap kelembagaan dan tulisan tersebut belum mengkaji sejauh mana kebijakan dan kurikulum menjadi out put atau hasil dari proses pendidikan. ${ }^{8}$

Demikian pula artikel berjudul "Integrasi Ilmu-Ilmu Keislaman dalam Perspektif M. Amin Abdullah" oleh Prahulutun Siregar. Hasil penelitian yang yang dimuat pada jurnal MIQOT Vol. XXXVIII No. 2 Juli-Desember 2014 ini membahas konsep dan model integrasi ilmu menurut M. Amin Abdullah. Pembahasan tulisan tersebut membedah sebagian pemikiran M. Amin Abdullah tentang integrasi ilmu. ${ }^{9}$

Adapun tulisan Integrasi

Pengetahuan Umum dan Keislaman di Indonesia: Studi Integrasi Keilmuan di Universitas Islam Negeri di Indonesia oleh Miftahuddin dalam jurnal Attarbiyah, Journal of Islamic Culture and Education

$8 \quad$ Nurlena Rifai, dkk., "Integrasi Keilmuan dalam Pengembangan Kurikulum di UIN Se-Indonesia: Evaluasi Penerapan Integrasi Keilmuan UIN dalam Kurikulum dan Proses Pembelajaran" Jurnal TARBIYA Vol. I, No.1, Juni 2014.

9 Prahulutun Siregar, "Integrasi Ilmu-Ilmu Keislaman dalam Perspektif M. Amin Abdullah" Jurnal MIQOT Vol. XXXVIII No. 2 JuliDesember 2014.
Vol. I, No. 1, Juni 2016 membahas tentang wacana adan konsep abstrak tentang integrasi ilmu di UIN Jakarta, UIN Yogyakarta dan UIN Malang. Tulisan tersebut tidak meneliti hasil dari integrasi ilmu pada masing-masing UIN. ${ }^{10}$

Dengan demikian, penelitian tentang Integrasi Ilmu Agama dan Sains di Indonesia: Studi Penulisan Skripsi di UIN Syarif Hidayatullah Jakarta memiliki distingsi yang berbeda dengan penelitianpenelitian sebelumnya, baik pada aspek objek, metode penelitian, maupun tujuannya.

Metode yang digunakan dalam penelitian ini adalah mix method, yaitu metode gabungan metode kualitatifkuantitatif. Fokus penelitian ini terkait kajian integrasi ilmu agama dan sains dalam penulisan skripsi di UIN Syarif Hidayatullah Jakarta. Adapun objek penelitiannya adalah skripsi mahasiswa di bidag sains pada Fakultas Sains dan Teknologi UIN UIN Syarif Hidayatullah Jakarta. Sample yang ijadikan objek peneltian sebanyal 45 skrispi dari kurun 2015-2019 masing-masing lima skrispi pada tiap satu tahun. Sample diambil secara acak (random).

Data dari sample kemudian dikumpulkan, lalu dibuat analisa dan hipotesa kemudian simpulkan. Selain itu, untuk menguatkan hasil temuan penelitian ini juga didukung dengan wawancara dengan stakeholder, misalnya pimpinan fakultas/dosen.

Untuk menguji ada dan tidaknya proses dan/, atau hasil integrasi ilmu agama dan sains dalam penulisan skripsi dibuat sejumlah indikator dengan menggunakan istilah-istilah pokok (basic terminilogy) atau kata-kata kunci Islam (Islamic key world) seperti Allah, Tuhan, Pencipta, Islam, Quran, Hadis, Nabi, 10 Miftahuddin, "Integrasi Pengetahuan Umum dan Keislaman di Indonesia: Studi Integrasi Keilmuan di Universitas Islam Negeri di Indonesia', Jurnal Attarbiyah, Journal of Islamic Culture and Education Vol. I, No. 1, Juni 2016. 
Rasul, Muhammad, jujur, adil, sejahtera, benar, dan amanah untuk teks yang berbahasa Indonesia. Adapun untuk teks berbahasa Arab menggunakan kata

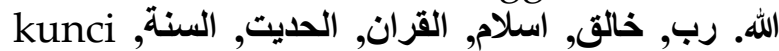

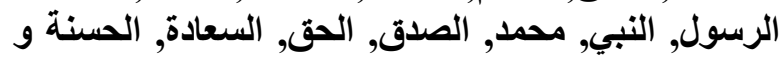
الأمانة. Untuk teks yang berbahasa Inggris menggunakan kata kunci Allah, God, The Creator, Lord, Islam, Qur'an, Hadith, Messenger, Prophet, Mohammad, justice, honesty, trust, and prosperous.

Dalam studi teologi dan filsafat katakata kunci tersebut di atas merupakan tema-tema, inti (core), pokok besar dan dasar dalam Islam. Tidak ada kajian, penelitian dan pembahasan pelbagai narasi, isu, dan perdebatan yang lebih tajam dan sengit serta menarik tanpa mengaitkan tema-tema besar tersebut di atas. ${ }^{11}$ Demikian pula dalam kajian Alquran dan tafsirnya. ${ }^{12}$ Dalam $A l-M u$ 'jam al-Mufahras li al-Fâzh al-Qur'ân al-al-Karîm, misalnya, istilah Allâh, ilâh, Rabb, nabî, rasûl, dan Alqur'ân atau al-Kitâb adalah istilah yang paling sering dan banyak diulang-ulang dalam Alquran. ${ }^{13}$

Dengan memasukkan istilah-istilah pokok tersebut pada softcopy skripsi melalui tombol F, sebuah skripsi akan terbaca apakah dalam kajian atau kerangka teoritis (Bab Pendahuluan) dan Bab Pembahasannya ditemukan istilahistilah tersebut serta penjabaran dan analisisinya.

\begin{tabular}{ccccccc}
\hline $\begin{array}{c}\text { Program } \\
\text { Studi }\end{array}$ & $\begin{array}{c}\text { Tahun } \\
\text { terbit }\end{array}$ & No & Judul & Penulis & $\begin{array}{c}\text { Indikator } \\
\text { Integrasi }\end{array}$ \\
\hline 1 & 2 & 3 & 4 & 5 & & 6 \\
\hline
\end{tabular}

11 Abû Bakar Jâbir al-Jazâirî, 'Aqîidah al-Mu'min, (Madînah: Maktabah al-'Ulûm wa al-Hikam, 2004). Baca pula 'Abduh al-Syamâlî, Târîkh al-Falsafah al'Arabiyah al-Islâmiyah wa Atsâru Rijâluhâ, (Beirut: Dâr al-Shâdir, 1979) dan Amsal Bakhtiar, Tema-tema Filsafat Islam, (Jakarta: UIN Jakarta Press, 2005).

12 M. Quraish Shihab, Wawasan Al-Qur'an, (Bandung: Mizan, 1996), cet. III.

13 Muhammad Fuad Abdul Baqi, Al-Mu'jam al-Mufahras li al-Fâzh al-Qur'ân al- al-Karîm, (Bandung: CV Diponegoro, tth) dan Majduddin Muhammad bin Ya'qûb al-Fairûz-âbâdî, Al-Qâmûs al-Muhîth, (Kairo: Dar al-Hadîts, 2008).
Kode indikator integrasi ilmu dibuat berjenjang. Indikator integrasi ilmu pada judul diberi kode (1), penggunaan ayat dan hadis pada uraian diberi kode (2) dan pada nilai keislaman diberi kode (3), sedangkan angka 0 dijadikan kode untuk skripsi yang tidak ada unsur 1, 2, dan 3.

Adapun pendekatan yang digunakan untuk mengkaji obyek penelitian adalah metode studi kasus dan analisis kritis. Metode studi kasus ialah suatu serangkaian kegiatan ilmiah yang dilakukan secara intensif, terinci dan mendalam tentang suatu aktivitas, program, dan peristiwa, baik pada terjadi pada perorangan, sekelompok orang, lembaga, atau organisasi untuk memperoleh pengetahuan mendalam tentang peristiwa tersebut. ${ }^{14}$

\section{INTEGRASI ILMU AGAMA DAN SAINS}

Secara etimologi kata integrasi berasal dari bahasa inggris "integration", yang berarti kesempurnaan atau keseluruhan. Dalam bahasa Arab, istilah integrasi sepadan dengan kata takâmul (تكامل). Kata tersebut berasal dari kata $k a-$ mi-la (كل) yang berarti lengkap, penuh, utuh, keseluruhan, total, sempurna, dan tuntas. ${ }^{15}$ Dengan demikian kata integrasi dapat diartikan sebagai pembauran hingga menjadi kesatuan yang utuh atau bulat. Integrasi juga bisa diartikan penyesuaian atau penyatuan antara satu unsur dengan unsur yang lain. ${ }^{16}$

Dari pengertian di atas dapat dikatakan bahwa integrasi ilmu dengan sains

14 Mujia Rahardjo, Studi Kasus dalam Penelitian Kualitatif: Konsep dan Prosedurnya, (Malang: Universitas Islam Negeri Maulana Malik Ibrahim Malang, 2017), hlm. 3.

15 Baca https://www.almaany.com/id/dict/arid/\%D9\%83\%D9\%85\%D9\%84/? Baca juga Abû al- Husain Ahmad ibn Fâris ibn Zakariya, Maqâyis al-Lugah, Juz. I (Bairut: Ittihad al-Kitâb al-'Arabi, 2002), Ibrâhîm Musthaafâ, dkk., alMu'jam al-Wasîth\}, Juz. I (CD-ROM al-Maktabah al-Syamilah) dan Munawwir, A.W., Kamus AlMunawwir Arab-Indonesia, (Yogyakarta: Pustaka Progresif, 1997), cet. XIV.

16 Lihat https://kbbi.web.id/integrasi. 
adalah membaurkan, atau menyesuaikan pandangan ilmu agama dan sains pada satu masalah tertentu sehingga terjadi kesatupaduan konsep yang utuh.

Dalam Islam secara filosofis tidak dikenal istilah ilmu agama dan ilmu umum atau lainnya. Alasannya, semua ilmu berasal dari Allah SWT. Bentuk dan sifat ilmu Allah itu kullî (كلي), yaitu menyeluruh dan utuh, sehingga menjadi satu kesatuan. Ketika ilmu Allah beremanasi pada manusia, ilmu tersebut menjadi juz-î (جزئي), yaitu parsial dan terpisah, sehingga menjadi bagian-bagian tertentu. Kendati menjadi bagian-bagian pelbagai disiplin ilmu, secara ontologis masing-masing tetap bersifat suci, sakral, integral dalam kehidupan dunia dan akhirat, serta bermakna bagi kehidupan.

Pada sisi lan, tak dapat diragukan lagi bahwa setiap kehidupan seorang Muslim dan masyarakatnya selalu dibingkai oleh norma (ilmu) agama. Dalam Islam, pelbagai jenis ilmu atau sains lahir dan berkembang karena doktrin agama. Ini artinya kehidupan manusia tidak bisa lepas dari ilmu agama dan sains.

Seseorang yang hendak puasa Ramadlan, ia harus mengetahui fikih puasa. Pada sisi lain ia harus tahu kapan awal Ramadlan tiba. Dengan demikian peristiwa Ramadhan mengharuskan seorang Muslim mengetahui ilmu Fikih dan Falak atau Fisika. Pedagang yang benar dalam pandangan Islam adalah ia yang paham ilmu Ekonomi, Kalam, dan Fikih, sehingga ia terhindar dari sistem dan praktek riba. Demikianlah integrasi ilmu dalam Islam.

Secara historis pada masa Nabi Muhammad SAW, demikian pula pada peradaban Yunani klasik, ilmu belum terklasifikasi dan terdominasi pada satu bidang tertentu. Klasifikasi atau pembagian rumpun ilmu dilakukan para ahli untuk memudahkan cara mempelajari masingmasing ilmu. Selain karena mempunyai metodologi yang tidak sama, masingmasing ilmu juga mempunyai filosofi dan aspek aksiologi yang tidak sama pula.
Metodologi dan filosofi ilmu Astronomi berbeda dengan ilmu Akuntansi. Demikian pula ilmu-ilmu yang lain.

Secara epistemologis, Ibn Khaldûn membagi ilmu pada dua kelompok, yaitu: ilmu-ilmu aqliyah dan ilmu-ilmu naqliyah. Ilmu-ilmu aqliyah dihasilkan karena penalaran akal. Sedangkan ilmu-ilmu naqliyah bersifat manqûl. Artinya, ilmuilmu ini bersumber dari wahyu, bukan dari penalaran akal, kecuali dalam masalah furû'iyah. ${ }^{17}$

Ibn Khaldun menegaskan, karena sumber, sifat dan karakternya langsung dari Allah SWT dan Rasul-Nya sebagai pemilik otoritas, maka ilmu-ilmu naqliyah harus diutamakan dan didahulukan pemahaman dan penguasaannya.

Pendapat ini didukung oleh Abû al-Hasan al-Mawardí (364-450 H). Menurutnya, ilmu-ilmu agama (naqliyah) merupakan ilmu yang paling utama dan harus didahulukan pengkajian dan pendalamannya.

Menurutnya, tanpa ilmu tersebut sulit bagi seseorang mendapatkan petunjuk Allah SWT dan ia tersesat karena kebodohannya terhadap ilmu-ilmu naqliyah. Selain itu, tidak sah ibadah seseorang bila ibadahnya tidak didasari dengan ilmu tersebut, karena ia tidak mengetahui syarat, tata cara dan sarana beribadah. ${ }^{18}$

$$
\text { Jauh sebelum itu, al-Farabi }
$$
mengklasifikasi ilmu ke dalam lima bagian, tanpa merinci tingkatan masingmasing ilmu. Lima kelompok ilmu itu adalah ilmu lisan (bahasa), logika, ilmu bilangan (matematika), ilmu alam (fisika) dan metafisika, serta ilmu kemasyarakatan (madani), fikih, dan teologi/kalam. Kelima ilmu pengetahuan ini telah mewarnai nafas peradaban Islam pada masa itu.

Sebagaimana dijelaskan pada Ihshâ-u al'Ulûm, al-Farabi membagi ilmu bahasa pada

17 Ibn Khaldûn, Muqaddimah Ibn Khaldûn, (Kairo: Dar NahdLah Mishr li al-Thab' wa Nasyr), hlm. 1026-1027.

18 al-Mawardi, Abû al-Hasan 'Ali bin Muhammad bin Habîb al-Bishri. Adâb al-Dunyâ wa al-Dîn, (Jeddah: al-Haramain, tth), hlm. 44. 
empat cabang, yaitu: gramatika, sintaksis (ilmu tarkib al-kalam), syair, menulis dan membaca.

Agar seseorang terhindar salah dalam membuat ungkapan, maka diperlukan ilmu logika. Dengan mempelajari logika, maka orang akan terhindari dari kesalahankesalahan bertutur kata, baik dalam menyimpulkan pikiran maupun dalam bersyair. Oleh karena itu, ilmu logika itu lebih dipandang bersifat seni dari pada sifatnya sebagai ilmu. Orang Arab juga memasukkan ilmu balaghah (retorika) dan syair menjadi bagian dari ilmu logika.

Menurutnya, rumpun ilmu yang termasuk bagian dari matematika, yaitu: aritmatika, geometri, optika, astronomi, musik, ilmu ukur, (Latin: arte ponderum), dan mekanika.

Sedangkan yang tergolong ilmu alam (fisika) adalah ilmu-ilmu yang mengkaji halhal yang rerkait dengan materi, baik yang terdapat pada bumi maupun alam semesta, seperti logam dan kaca (kimia), tumbuhan (ilmu nabati), hewan (zoology), dan lainlain.

Sementara ilmu-ilmu metafisika meliputi studi tentang segala wujud yang tidak dibahas pada ilmu fisika. Ilmu ini juga sering disebut sebagai al-falsafah alula, karena tema pokok dari studi ilmu ini adalah mengkaji wujud yang mutlak, yaitu Allah SWT. ${ }^{19}$

Menurut al-Farabi, rumpun ilmu kemasyarakatan meliputi ilmu hukum, pranata sosial etika, dan politik. Adapun ilmu fikih adalah ilmu yang mengkaji perilaku manusia berdasarkan hukumhukum syariat. Sedangkan ilmu kalam adalah ilmu yang membahas keyakinan agama-agama manusia, baik perbuatan maupun ucapan-ucapannya.

Pada dasarnya semua ilmu adalah sains dan sains juga bermakna ilmu. Husain Hamâdah dalam bukunya Târîkh al-'Ulûm 'Inda al-'Arab, contohnya, mengkategorikan

19 al-Farabi, Abu Nashr,.Ihshâ-u al-'Ulûm, (Dâr wa Maktabah al-Hilâl, 1996), hlm. 67. semua bidang kajian, baik kimia, fisika, musik, matematika, ilmu bangun ruang, teknik, dan falak, maupun sejarah sebagai ilmu. ${ }^{20}$

Terlepas dari pendapat-pendapat di atas, menurut Pasal 10 ayat 1 dan 2 UndangUndang Republik Indonesia Nomor 12 Tahun 2012 tentang Pendidikan Tinggi, ilmu pengetahuan dan teknologi diklasifikasi ke dalam enam rumpun, yaitu, a) rumpun ilmu agama;b) rumpun ilmu humaniora; c) rumpun ilmu sosial; d) rumpun ilmu alam;e0rumpun ilmu formal; dan f) rumpun ilmu terapan.

Mengacu pada penjelasan Pasal di atas, ilmu-ilmu naqliyah-syar'iyah atau metafisika sebagaimana disebutkan Ibn Khaldun, al-Farabi dan lain-lainnya, adalah rumpun ilmu agama.

Penjelasan lebih mendalam tentang UU tersebut termaktub dalam Peraturan Menteri Pendidikan dan Kebudayaan Republik Indonesia Nomor 154 Tahun 2014 Tentang Rumpun Ilmu Pengetahuan dan Teknologi Serta Gelar Lulusan Perguruan Tinggi. Dalam Pasal 2 butir 5 peraturan tersebut, disebutkan bahwa rumpun ilmu alam adalah ilmu pengetahuan yang mengkaji dan mendalami alam semesta, yaitu fisika, biologi dan kimia.

Karena pengaruh sekulerisme, ${ }^{21}$ agama dan ilmu pengetahuan (sains) menjadi dikhotomis, saling bertentangan, dan keduanya membentuk entititas serta identitas sendiri-sendiri.

Menurut Ian G. Barbour, terdapat empat pola hubungan antara agama

20 Husain Hamâdah, Târikh al-Ulưm 'inda al-'Arab, (Beirut: al-Syirkah al-'Alamiyah li al-Kitab, 1987).

21 Sekularisme adalah pembebasan manusia dari pandangan hidup keagamaan dan metafisika, pengalihan dari alam lain kepada dunia ini. Secara bahasa sekularisme berasal dari kata Latin saeculum. Kata ini sepadan dengan kata yang berarti wordly keduniaan dan menolak nilai-nilai spiritual. Baca The New International Webster's Compeherensive Dictionary of the English Languange, (Chicago: Trident Press International, 1974) hlm. 1138 dan Adnin Armas, "Sebuah Catatan Untuk Sekularisasi Harvey Cox',dalam Majalah ISLAMIA. 2007. Vol. III No. 2. hlm. 28. 
dan ilmu, yaitu konflik (bertentangan), independensi (masing-masing berdiri sendiri-sendiri), dialog (berkomunikasi) atau integrasi (menyatu dan bersinergi). ${ }^{22}$ Pola keempat (integrasi) menurut sebagian kalangan dianggap sesuai dengan konsep pendidikan Islam. ${ }^{23}$

Untuk kepentingan implementasi integrasi ilmu agama dan sains, UIN Jakarta mewacanakan dan mendesain konsep integrasi ilmu agama dengan sains. Menurut UIN Jakarta, integrasi ilmu adalah penyatuan ilmu kegamaan Islam dengan ilmu-ilmu lain, sehingga ilmu-ilmu tersebut tidak saling bertentangan dan dikotomis. ${ }^{24}$ Dengan konsep demikian diharapkan terjadi integrasi antara ilmu agama dan ilmu-ilmu lain (humaniora, sosial, alam, formal dan terapan).

Secara konseptual, UIN Jakarta melakukan integrasi ilmu dalam berbagai bentuk sebagai berikut: (1) Ilmu-ilmu agama (Islam) dipertemukan dengan ilmuilmu sains-teknologi; (2) ilmu-ilmu agama (Islam) dipertemukan dengan ilmu-ilmu sosial humaniora dan (3) ilmu-ilmu sainsteknologi dipertemukan dengan ilmu-ilmu sosial humaniora. Metode yang terbaik adalah mempertemukan ketiga-tiganya (ilmu-ilmu agama (Islam), ilmu-ilmu sainsteknologi, dan ilmu-ilmu sosial-humaniora).

Interaksi antara ketiga disiplin ilmu tersebut akan memperkuat satu sama lain, sehingga bangunan keilmuan masingmasing akan semakin kokoh. Upaya mempertemukan ketiga disiplin ilmu tersebut diperkuat dengan disiplin ilmu filsafat. Tiga serangkai objek filsafat, yaitu ontologi, epistemologi, dan aksiologi digunakan untuk mempertemukan ketiga disiplin ilmu tersebut.

22 Ian G. Barbour, Issues in Science and Religion (New York: Harper Torchbooks, 2002), hlm.. 55-56

23 M. Amin Abdullah, Islamic Studies dalam Paradigma Integrasi-Interkoneksi, (Yogyakarta : Suka Press, 2007).

24 Pedoman Integrasi Ilmu UIN Syarif Hidayatullah, (Senat UIN Syarif Hidayatullah Jakarta, 2018), hlm. 9.
Untuk mengimplementasikan gagasan integrasi, UIN Jakarta mewajibkan bagi seluruh mahasiswanya belajar sejumlah mata kuliah tertentu,-seperti Studi Islam, Bahasa Arab, Praktikum Qiraat dan Ibadah, Islam dan Ilmu Pengetahuan, Islam dan Teknologi Informasi, dan lain-lainnya,sebagai komitmen pada Islamic values.

\section{HASIL DAN PEMBAHASAN}

Penelitian ini menguji dan menganalisa aspek integrasi agama dan sains pada 45 skripsi mahasiswa Program Studi Biologi, Fisika, dan Kimia Fakultas Sains dan Teknologi pada UIN Jakarta.

Aspek integrasi dapat dilihat pada kebijakan dan implementasinya baik berupa proses, hasil pendidikan dan penelitian, maupun sikap mahasiswa. Untuk melihat adanya integrasi ilmu, penulis menggunakan beberapa indikator sebagaimana disebutkan pada bagian sebelumnya, yaitu: 1) penulisan judul/tema dalam judul diberi kode 1;2) penggunaan ayat dan hadis pada uraian diberi kode (2) dan 3) pada nilai keislaman diberi kode (3), sedangkan angka 0 dijadikan kode untuk karya ilmiah yang tidak ada unsur 1,2, dan 3.

Penulisan skripsi menjadi salah satu indikator penting, obyektif, aktual dan orisinal, karena skripsi merupakan karya ilmiah dari hasil proses belajar mengajar antara dosen dengan mahasiswa, dan tentunya skripsi merupakan out come intelektual dari seorang sarjana.

Penelitian ini mengambil 45 skripsi mahasiswa sebagai sample. Judul-judul skripsi tersebut adalah sebagai berikut: ${ }^{25}$

25 Baca laman-laman berikut: https://fst.uinjkt. ac.id/, http://bio.fst.uinjkt.ac.id/, fis.fst.uinjkt. ac.id, dan http://kim.fst.uinjkt.ac.id/ 
Integrasi Ilmu Agama...(Saifudin)

\begin{tabular}{|c|c|c|c|c|c|c|c|}
\hline \multirow{2}{*}{$\begin{array}{l}\text { Program } \\
\text { Studi }\end{array}$} & \multirow{2}{*}{$\begin{array}{l}\text { Tahun } \\
\text { Terbit }\end{array}$} & \multirow[t]{2}{*}{ No } & \multirow[t]{2}{*}{ Judul } & \multirow[t]{2}{*}{ Penulis } & \multicolumn{3}{|c|}{$\begin{array}{l}\text { Indikator } \\
\text { Integrasi }\end{array}$} \\
\hline & & & & & $\mathbf{0}$ & 12 & 3 \\
\hline 1 & 2 & 3 & 4 & 5 & & 6 & \\
\hline \multirow[t]{15}{*}{ Fisika } & 2014 & 1 & $\begin{array}{l}\text { Analisis Perbandingan Rangkaian Transimpedansi Amplifier } \\
\text { Ganda Dan Rangkaian Fotokonduktif Ganda Untuk Sensor } \\
\text { Weight In Motion Berbasis Serat Optik }\end{array}$ & Nur Taufik Zamari & 0 & & \\
\hline & & 2 & $\begin{array}{l}\text { Pengembangan Sistem Monitoring Vibrasi Pada Kipas } \\
\text { Pendingin Menggunakan Accelerometer Adxl345 Dengan } \\
\text { Metode Fft Berbasis Labview }\end{array}$ & $\begin{array}{l}\text { Irman Supriadi } \\
\text { Adistya }\end{array}$ & 0 & & \\
\hline & & 3 & $\begin{array}{l}\text { Identifikasi Kualitas Air Berdasarkan Nilai Resistivitas Dan } \\
\text { Hubungannya Dengan Parameter Kimia }\end{array}$ & Rino Amalsa & 0 & & \\
\hline & 2015 & 4 & $\begin{array}{l}\text { Aplikasi Metode Geolistrik Resisvitas Untuk Mengidentifikasi } \\
\text { Lapisan Akuifer Di Bumi Perkemahan Ragunan Jakarta } 0\end{array}$ & $\begin{array}{l}\text { Agesti } \\
\text { Kusumandari }\end{array}$ & 0 & & \\
\hline & & 5 & $\begin{array}{l}\text { Rancang Bangun Dan Karakterisasi Sensor Extensometer } \\
\text { Berbasis Incremental Rotary Encoder Sebagai Pendeteksi } \\
\text { Dini Tanah Longsor }\end{array}$ & $\begin{array}{l}\text { Mamduh Dliyaul } \\
\text { Jawwad }\end{array}$ & 0 & & \\
\hline & & 6 & $\begin{array}{l}\text { Optimasi Sintesis Li4ti5o12 Dengan Penambahan Lioh.H2O } \\
\text { Untuk Anoda Baterai Ion Lithium }\end{array}$ & $\begin{array}{l}\text { Raras Dewi Prima } \\
\text { Ekasari }\end{array}$ & 0 & & \\
\hline & 2016 & 7 & $\begin{array}{l}\text { Penentuan Kondisi Lapisan Akuifer Di Daerah “ 'X” Dengan } \\
\text { Menggunakan Metode Geolistrik Tahanan Jenis }\end{array}$ & $\begin{array}{l}\text { Devis Sika } \\
\text { Homisia }\end{array}$ & 0 & & \\
\hline & & 8 & $\begin{array}{l}\text { Pengaruh Variasi Penambahan Plasticizer Gliserol Terhadap } \\
\text { Konduktivitas Elektrolit Padat Berbasis Polimer Komposit } \\
\text { Kitosan-Zro2-Liclo4 }\end{array}$ & $\begin{array}{l}\text { Dayu Luthfiah } \\
\text { Luthfi }\end{array}$ & 0 & & \\
\hline & & 9 & $\begin{array}{l}\text { Studi Tingkat Kekerasan (Vickers) Bahan Komposit Serbuk } \\
\text { Kayu Dengan Matrik Epoxy }\end{array}$ & $\begin{array}{l}\text { Azam Ibrahim } \\
\text { Ghufran }\end{array}$ & 0 & & \\
\hline & 2017 & 10 & $\begin{array}{l}\text { Reduksi Multiple Pada Data Seismik 2d Marine } \\
\text { Menggunakan Metode Migrasi Frekuensi - Bilangan } \\
\text { Gelombang (F-K) }\end{array}$ & $\begin{array}{l}\text { Tiara Adelia } \\
\text { Primana Bhakti }\end{array}$ & 0 & & \\
\hline & & 11 & $\begin{array}{l}\text { Analisis Dan Karakterisasi Magnet Bafe12o19 Dengan } \\
\text { Penambahan Aditif La2o3 }\end{array}$ & Teddy Bastian & 0 & & \\
\hline & & 12 & $\begin{array}{l}\text { Demultiple Gelombang Seismik Menggunakan Teknik Srme } \\
\text { (Surface Related Multiple Elimination) Pada Pengolahan } \\
\text { Data Seismik } 2 d \text { Laut }\end{array}$ & Alfandi Ali Akbar & 0 & & \\
\hline & 2018 & 13 & $\begin{array}{l}\text { Jalan Perkici Xvii Blok Eb Rt. 05/06, Kel. Jurang Mangu } \\
\text { Barat, Kec. Pondok Aren, Kota Tangerang Selatan, Banten. } \\
15223\end{array}$ & $\begin{array}{l}\text { Adl Shahida Ismail } \\
\text { Datu-Maki }\end{array}$ & 0 & & \\
\hline & & 14 & $\begin{array}{l}\text { Rancang Bangun Smart Home Menggunakan Wemos D1 R2 } \\
\text { Arduino Compatible Berbasis Esp } 8266 \text { Esp-12f }\end{array}$ & $\begin{array}{l}\text { Nurul Aditya Ayu } \\
\text { Kusuma }\end{array}$ & 0 & & \\
\hline & & 15 & $\begin{array}{l}\text { Analisis Repetitive Control Untuk Rejection Multiple } \\
\text { Periodical Disturbances Dengan Menggunakan Scilab Xcos }\end{array}$ & $\begin{array}{l}\text { Nizarrachman } \\
\text { Hadi }\end{array}$ & 0 & & \\
\hline
\end{tabular}


PROFETIKA, Jurnal Studi Islam, Vol.21, No. 1, Special Issue 2020: 78-90

\begin{tabular}{|c|c|c|c|c|c|c|c|}
\hline \multirow{2}{*}{$\begin{array}{l}\text { Program } \\
\text { Studi }\end{array}$} & \multirow{2}{*}{$\begin{array}{l}\text { Tahun } \\
\text { Terbit }\end{array}$} & \multirow{2}{*}{ No } & \multirow{2}{*}{ Judul } & \multirow{2}{*}{ Penulis } & \multicolumn{3}{|c|}{$\begin{array}{l}\text { Indikator } \\
\text { Integrasi }\end{array}$} \\
\hline & & & & & $\overline{0}$ & 12 & 3 \\
\hline 1 & 2 & 3 & 4 & 5 & & 6 & \\
\hline \multirow[t]{15}{*}{ Biologi } & 2014 & 16 & $\begin{array}{l}\text { Efisiensi Penggunaan Pupuk Anorganik Dengan Aplikasi } \\
\text { Effective Microorganism } 10 \text { (Em10) Pada Tanaman Kedelai } \\
\text { (Glycine Max (L) Merill) }\end{array}$ & $\begin{array}{l}\text { Astina } \\
\text { Yulianingsih }\end{array}$ & 0 & & \\
\hline & & 17 & $\begin{array}{l}\text { Keanekaragaman Jenis Dan Distribusi Family Tridacnidae } \\
\text { (Kerang Kima) Di Perairan Pulau Karang Congkak, } \\
\text { Kepulauan Seribu }\end{array}$ & $\begin{array}{l}\text { Qorimeifebria } \\
\text { Rizkevina }\end{array}$ & 0 & & \\
\hline & & 18 & $\begin{array}{l}\text { Keanekaragaman Tumbuhan Obat Di Taman Nasional } \\
\text { Gunung Gede Pangrango Dan Di Hutan Terfragmentasi } \\
\text { Kebun Raya Cibodas Serta Pemanfaatannya Oleh } \\
\text { Masyarakat Lokal }\end{array}$ & Irpan Fahrurozi & 0 & & \\
\hline & 2015 & 19 & $\begin{array}{l}\text { Identifikasi Dan Deskripsi Fungi Penyebab Penyakit Pada } \\
\text { Tanaman Kacang Panjang (Vigna Sinensis L.) }\end{array}$ & $\begin{array}{l}\text { Liany Anna } \\
\text { Rahayu }\end{array}$ & 0 & & \\
\hline & & 20 & $\begin{array}{l}\text { Kualitas Udara Pada Ruang Tunggu Puskesmas Perawatan } \\
\text { Ciputat Timur Dan Non-Perawatan Ciputat Di Daerah } \\
\text { Tangerang Selatan Dengan Parameter Jamur }\end{array}$ & Nailul Izzah & 0 & & \\
\hline & & 21 & $\begin{array}{l}\text { Keanekaragaman Kumbang Sungut Panjang (Coleoptera: } \\
\text { Cerambycidae) Di Kawasan Resort Salak } 2 \text { - Taman Nasional } \\
\text { Gunung Halimun Salak (Tnghs) }\end{array}$ & Ega Mulya Putri & 0 & & \\
\hline & 2016 & 22 & $\begin{array}{l}\text { Potensi Pupuk Azolla Pinnata Untuk Pengurangan } \\
\text { Penggunaan Pupuk Anorganik Pada Budi Daya Terung } \\
\text { (Solanum Melongena L.) }\end{array}$ & Moh. Rifqi & 0 & & \\
\hline & & 23 & $\begin{array}{l}\text { Produksi Biogas Dari Feses Gajah Sumatera (Elephas } \\
\text { Maximus Sumatranus Temminck, 1847) Terhadap Jenis Pakan } \\
\text { Yang Diberikan Di Taman Margasatwa Ragunan, Jakarta } \\
\text { Selatan }\end{array}$ & Fuad Albani & 0 & & \\
\hline & & 24 & $\begin{array}{l}\text { Isolasi Bakteri Pelarut Fosfat Asal Guano Kelelawar } \\
\text { Pemakan Serangga Dan Guano Kelelawar Pemakan Buah }\end{array}$ & $\begin{array}{l}\text { Dara Mutiara } \\
\text { Fiesca }\end{array}$ & 0 & & \\
\hline & 2017 & 25 & $\begin{array}{l}\text { Desulfurisasi Bahan Bakar Solar Oleh Bakteri Moraxella } \\
\text { Osloensis }\end{array}$ & Nurfauziah & 0 & & \\
\hline & & 26 & $\begin{array}{l}\text { Aktivitas Formula Yang Mengandung Ekstrak Biji Klabet } \\
\text { (Trigonella Foenum Graceum L.) Terhadap Tikus Spraque } \\
\text { Dawley Yang Diinduksi Streptozotocin }\end{array}$ & $\begin{array}{l}\text { Maulana Malik } \\
\text { Assayiddin }\end{array}$ & 0 & & \\
\hline & & 27 & $\begin{array}{l}\text { Aktivitas Desulfurisasi Micrococcus Endophyticus Dalam } \\
\text { Bahan Bakar Solar }\end{array}$ & Eka Syafiqa & 0 & & \\
\hline & 2018 & 28 & $\begin{array}{l}\text { Struktur Komunitas Kapang Endofit Tanaman Pegagan } \\
\text { (Centella Asiatica (L.) Urb.) Aksesi Bengkulu }\end{array}$ & $\begin{array}{l}\text { Jeanne Isbeanny } \\
\text { Laraswari F.H }\end{array}$ & 0 & & \\
\hline & & 29 & $\begin{array}{l}\text { Komunitas Kupu-Kupu (Lepidoptera:Rhopalocera) di Hutan } \\
\text { Sokokembang, Pekalongan, Jawa Tengah }\end{array}$ & Sarah Nuraini & 0 & & \\
\hline & & 30 & $\begin{array}{l}\text { Penambahan Ekstrak Daun Pepaya Untuk Mereduksi Gas } \\
\text { Metana Cairan Rumen Kambing Jawa Secara In Vitro }\end{array}$ & $\begin{array}{l}\text { Aditya Pratama } \\
\text { Putra }\end{array}$ & 0 & & \\
\hline
\end{tabular}


Integrasi Ilmu Agama...(Saifudin)

\begin{tabular}{|c|c|c|c|c|c|c|c|}
\hline \multirow{2}{*}{$\begin{array}{l}\text { Program } \\
\text { Studi }\end{array}$} & \multirow{2}{*}{$\begin{array}{l}\text { Tahun } \\
\text { Terbit }\end{array}$} & \multirow[t]{2}{*}{ No } & \multirow[t]{2}{*}{ Judul } & \multirow[t]{2}{*}{ Penulis } & \multicolumn{3}{|c|}{$\begin{array}{l}\text { Indikator } \\
\text { Integrasi }\end{array}$} \\
\hline & & & & & $\mathbf{0}$ & 12 & 3 \\
\hline 1 & 2 & 3 & 4 & 5 & & 6 & \\
\hline \multirow[t]{15}{*}{ Kimia } & 2014 & & $\begin{array}{l}\text { Pirolisis Cangkang Kelapa Sawit Dan Catalytic Upgrading } \\
\text { Tar Menggunakan Katalis Berbasis Besi Oksida Untuk } \\
\text { Menghasilkan Senyawa Fenol }\end{array}$ & Prabowo & 0 & & \\
\hline & & & $\begin{array}{l}\text { Virtual Screening Inhibitor Alfa-Glukosidase Dari Database } \\
\text { Senyawa Aktif Tanaman Herbal Indonesia }\end{array}$ & Ahmad Triono & 0 & & \\
\hline & & & $\begin{array}{l}\text { Aktivitas Antioksidan Kombinasi Madu Monoflora Lokal } \\
\text { Dengan Ekstrak Daun Namnam (Cynometra Cauliflora L.) }\end{array}$ & Melina Hadera & 0 & & \\
\hline & 2015 & & $\begin{array}{l}\text { Karakterisasi Senyawa Hasil Isolasi Dari Ekstrak Metanol } \\
\text { Daun Namnam (Cynometra Cauliflora L.) Yang Memiliki } \\
\text { Aktivitas Antibakteri }\end{array}$ & Tiah Maharani & 0 & & \\
\hline & & & $\begin{array}{l}\text { Model Matematika Laju Pengeringan Dan Pengukuran } \\
\text { Kandungan Vitamin B6 Dan Warna Dalam Proses Pembuatan } \\
\text { Tepung Pisang Kepok (Musa Paradisiasal Formatypica) }\end{array}$ & $\begin{array}{l}\text { Sri Reny Dewi } \\
\text { Safitri }\end{array}$ & 0 & & \\
\hline & & & $\begin{array}{l}\text { Ekstraksi Glutation Dari Ragi Saccharomyces Cerevisiae } \\
\text { Hasil Pemisahan Sisa Fermentasi Bioetanol Dan Aktivitasnya } \\
\text { Sebagai Antioksidan }\end{array}$ & Elprida Pratiwi & 0 & & \\
\hline & 2016 & & $\begin{array}{l}\text { Kualitas Cairan Rumen Domba Jantan Yang Diberi Pakan } \\
\text { Silase Sorgum Varietas Samurai } 2 \text { Yang Mengandung } \\
\text { Probiotik Bios K2 }\end{array}$ & Nurani Hidayati & 0 & & \\
\hline & & & $\begin{array}{l}\text { Karakteristik Tablet Salut Selaput Fraksi Bioaktif Ekstrak } \\
\text { Daun Gambir Dengan Penyalut Opadry Amb }\end{array}$ & Indah Sulistyowati & 0 & & \\
\hline & & & Pelindian Bijih Laterit Dengan Asam Klorida & Pratama Arinaldo & 0 & & \\
\hline & 2017 & & $\begin{array}{l}\text { Karakterisasi Senyawa Aktif Antioksidan Dari Ekstrak Biji } \\
\text { Kecombrang (Etlingera Elatior) }\end{array}$ & $\begin{array}{l}\text { Dewi Atika } \\
\text { Ningsih }\end{array}$ & 0 & & \\
\hline & & & $\begin{array}{l}\text { Karakteristik Fermentabilitas Pakan Komplit Yang } \\
\text { Mengandung Jerami Padi, Daun Paitan (Tithonia } \\
\text { Diversifolia), Dan Daun Kirinyuh (Chromolaena Odorata) } \\
\text { Secara In Vitro }\end{array}$ & Ariani Dwi Putri & 0 & & \\
\hline & & & $\begin{array}{l}\text { Aktivitas Inhibitor Ace Fraksi Protein Susu Kerbau (Bubalus } \\
\text { Bubalis) Fermentasi }\end{array}$ & $\begin{array}{l}\text { Andhika Fajar } \\
\text { Pratama }\end{array}$ & 0 & & \\
\hline & 2018 & & $\begin{array}{l}\text { Upgrading Limbah Tar (Hasil Gasifikasi Batubara) Menjadi } \\
\text { Bahan Bakar Cair Sintetis Setara Minyak Diesel }\end{array}$ & Atti Sholihah & 0 & & \\
\hline & & & $\begin{array}{l}\text { Isolasi Dan Karakterisasi Senyawa Aktif Antioksidan Kapang } \\
\text { Endofit Aspergillus Elegans }\end{array}$ & $\begin{array}{l}\text { Ade Irma } \\
\text { Rahmawati }\end{array}$ & 0 & & \\
\hline & & & $\begin{array}{l}\text { Optimasi Katalis Hybrid Cu-Zno/Al2o3-Hzsm-5 Pada Sintesis } \\
\text { Dimetil Eter Dari Co Dan H2 (Syngas) }\end{array}$ & Tyas Puspita Rini & 0 & & \\
\hline Jumlah & & & & 45 & 45 & & \\
\hline
\end{tabular}

Dari judul dan kerangka teori serta pembahasan skripsi tersebut di atas, penulis menemukan bahwa 45 skripsi yang ditulis mahasiswa Program Studi Fisika, Biologi, dan Kimia FST UIN Jakarta tidak ditemukan indikator 1, 2, dan/ atau 3. Atau dalam bahasa lain, belum,untuk mengatakan tidak,- proses dan hasil integrasi (ilmu) agama dan sains. Ini artinya pada proses pembelajaran dan penulisan skripsi tidak terdapat desiminasi dan transfer of knowlegde serta internalisasi integrasi (ilmu) agama dan sains.

\section{ANALISIS KRITIS}

Ketiadaan (hasil) integrasi (ilmu) agama dan sains pada UIN Jakarta disebabkan beberapa faktor, yaitu: 1) narasi; 2) regulasi; dan 3) implementasi. Meskipun tiga faktor ini merupakan tiga variable yang tidak dapat dipisah- 
pisahkan. Satu faktor menjadi variable yang lain.

Faktor narasi adalah faktor yang paling pertama dan utama, karena ia menjadi titik awal (star point), sumber dan energi kebangkitan pemikiran integrasi ilmu agama dan sains, dan karenanya pula IAIN berubah menjadi UIN. Selama bertransformasi menjadi UIN, gelombang pemikiran integrasi ilmu di UIN Jakarta berjalan pasang surut, sehingga resonansi dan efek intonasinya pun berkembang sesuai dengan gelombang tersebut. Desiminasi dan sosialisi narasi integtrasi ilmu di UIN Jakarta belum menjadi isu utama, seksi, sentral dan penting bagi semua sivitas akademik. Kondisi demikian mendorong lahirnya status quo dominasi dikhotomi ilmu dan di sisi lain ilmu-ilmu sekuler menjadi dominan, baik secara akademis, ekonomis maupun sosiologis. Dampak lain dari hal tersebut adalah adanya alienasi ilmu pengetahuan tentang integrasi ilmu di kalangan sivitas akademik, khususnya bagi pada akademisinya.

Selanjutnya adalah faktor regulasi. Selama hampir dua dasawarsa, UIN Jakarta tidak membuat kebijakankebijakan atau norma-norma yang terkait dengan integrasi. Perumusan kebijakan integrasi ilmu di UIN Jakarta secara legalformal-material baru ditetapkan sebagai keputusan universitas pada 2017, yaitu pada Keputusan Rektor Nomor 864 Tahun 2017 tentang Integrasi Ilmu pada UIN Syarif Hidayatullah Jakarta. Ini artinya sejak berubah dan mewacanakan ide integrasi pada tahun 2000-an, UIN Jakarta belum melakukan langkah strategis dan taktis untuk membuat norma atau aturan serta turunan aturan baku tentang integrasi ilmu. Hal tersebut terjadi karena pemikiran integrasi UIN Jakarta tidak menjadi isu unggulan dan utama oleh sivitas akademik UIN Jakarta. Hal lain yang menjadi pemicu keterlambatan UIN Jakarta membuat regulasi integrasi ilmu adalah UIN Jakarta lebih fokus mengurusi dan memperbaiki masalah-masalah manajerial sarana-prasarana kampus dan isu-isu lain yang dianggap sensansional dan politis.

Pada faktor implementasi, UIN Jakarta belum melakukan usaha-usaha teknis aplikatif dan operasional dalam integrasi ilmu. Hal ini terbukti dengan tidak ditemukannya panduan operasional dan petunjuk pelaksanaan (juklak) dan petunjuk teknis (juknis) pada jenjang universitas dan fakultas serta program studi.

Pada sisi lain, UIN Jakarta juga belum berhasil dengan maksimal melakukan desiminasi dan sosialisasi integrasi ilmu, baik berupa pengilmuan pemikiran integrasi sebagai objek utama dalam kurikulum dan dalam pembuatan karya ilmiah dosen dan skripsi. Hal tersebut diakui oleh pimpinan Fakultas Sains dan Teknologi (FST) UIN Jakarta. Menurut Wakil Dekan Bidang Akademik FST UIN Jakarta Nashrul Hakim, FST belum mempunyai pedoman khusus tentang integrasi ilmu. Pengakuan tersebut selaras dengan hasil penelusuran penulis, bahwa FST sampai sekarang ini belum memiliki buku panduan penulisan skripsi dan karya ilmiah lainnya yang berbasis integrasi (ilmu) agama dan sains.

\section{SIMPULAN}

Dari paparan dan temuan pada uraian-uraian sebelumnya, penelitian ini menyimpulkan bahwa: Pertama, integrasi ilmu agama dan sains di UIN Jakarta berlansung hanya pada level wacana saja. Wacana integrasi ilmu agama dan sains berlangsung pasang surut seirama dengan gelombang pemikiran para pimpinannya dan belum menjadi isu sentral, narasi penting dan utama di kalangan sivitas akademik UIN Jakarta. Dengan demikian, regulasi dan pedoman atau juklak dan juknis integrasi juga tidak ditemukan. Kedua, karena ketiadaan kebijakan, 
norma, pedoman, juklak-juknis dan Dengan demikian dapat disimpulkan pendekatan operasional, integrasi ilmu secara umum bahwa transformasi IAIN agama dan sains pada penulisan skripsi Jakarta menjadi UIN Jakarta dengan mahasiswa FST tidak ditemukan. Atau mandat integrasi ilmu (agama) dan sains dalam bahasa lain, integrasi ilmu agama belum terwujid secara sistematis dan dan sains belum (tidak) terimplementasi. implementatif.

\section{DAFTAR PUSTAKA}

Abdul Hakim, Sudarnoto., dkk., 2006. Integrasi Keilmuan (Jakarta: UIN Pres)

Abdullah, M. Amin. 1995. Falsafah Kalam di Era Postmodernisme, (Pustaka Pelajar: Yogyakarta), cet. I, (Yogyakarta : Suka Press).

Abdussalam .1983. Sains dan dunia Islam, terj. Baiquni, (Bandung: Pustaka).

Abdul Baqi, Muhammad Fuad, tth. Al-Mu'jam al-Mufahras li al-Fâzh al-Qur'ân al-alKarîm, (Bandung: CV Diponegoro).

Ahmad ibn Fâris ibn Zakariya, Abû al-Husain. 2002. Maqâyis al-Lugah, Juz. I (Bairut: Ittihad al-Kitâb al-'Arabi).

Ahmed, Akbar S. Islam, 1994. Globalization and Post Modernism and Islam (London: Routledge).

Badara, Aris. 2012. Analisis Wacana: Teori, Metode, dan Penerapannya pada Wacana Media. (Jakarta: Kencana Prenada Media Group).

Barbour, Ian G. 2002. Issues in Science and Religion (New York: Harper Torchbooks).

Britanica 2001. 1999. Oxford University Press).

E., Sumaryono. 1993. Hermeuneutik: Sebuah Metode Filsafat, (Yogyakarta: Kanisius).

al-Fairûz-âbâdî, Majduddin Muhammad bin Ya'qûb, 2008. Al-Qâmûs al-Muhîth, (Kairo:

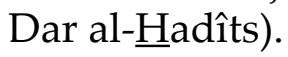

al-Farabi, Abu Nashr. 1996.Ihshâ-u al-'Ulûm, (Dâr wa Maktabah al-Hilâl).

al-Faruqi, Isma'il Raji. 1982. Tawhid: Its Implications for Thought and Life, terj. Rahmani Astuti, Tauhid, ( Bandung: PUSTAKA).

Fathurrahman, Oman. 2002. "Mewujudkan Mimpi IAIN Menjadi UIN" dalam Abuddin Nata, dkk.,Membangun Pusat Keunggulan Studi Islam, (Jakarta: IAIN Jakarta Press).

al-Ghazali, Abu Hamid Muhammad bin Muhammad al-Thusi, 1402 H/1982 M. Ihya Ulumuddin, (Beirut: Dar al-Ma'rifah), jilid ke-1.

Hamâdah, Husain. 1987.Târikh al-Uli̛m 'inda al-'Arab, (Beirut: al-Syirkah al-'Alamiyah li al-Kitab, 1987).

Ibn Khaldûn, tth.Muqaddimah Ibn Khaldûn, ditahkik 'Ali 'Abdulwahid Wafi, (Kairo: Dar NahdLah Mishr li al-Thab' wa Nasyr).

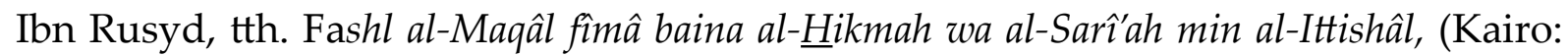


PROFETIKA, Jurnal Studi Islam, Vol.21, No. 1, Special Issue 2020: 78-90

Dâr al-Ma'ârif).

Jabali, Fuad dan Jamhari (ed), 2002. IAIN dan Modernisasi Islam di Indonesia, (Jakarta: Logos).

Kartanegara, Mulyadi. 2003. Integrasi Ilmu dalam Perspektif Filsafat Islam (Jakarta: UIN Press).

Keputusan Presiden Nomor 31 Tahun 2002.

Margono, S. 2005. Metodologi Penelitian Pendidikan, (Jakarta: Rineka Cipta).

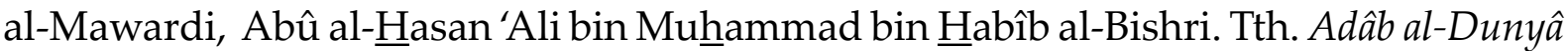
wa al-Dîn, (Jeddah: al- $\underline{\text { Haramain). }}$

Mitahuddin, "Integrasi Pengetahuan Umum dan Keislaman di Indonesia: Studi Integrasi Keilmuan di Universitas Islam Negeri di Indonesia', Jurnal Attarbiyah, Journal of Islamic Culture and Education Vol. I, No. 1, Juni 2016.

Musthaafâ, Ibrâhîm. dkk., al-Mu'jam al-Wasîth\}, Juz. I (CD-ROM al-Maktabah alSyamilah),

Munawwir, A.W., 1997. Kamus Al-Munawwir Arab-Indonesia, (Yogyakarta: Pustaka Progresif), cet. XIV.

Nata, Abudin., dkk. 2002. Membangun Pusat Keunggulan Studi Islam, (Jakarta: IAIN Jakarta Press).

Pedoman Akademik UIN Syarif Hidayatullah Jakarta 2018-2019, (Jakarta: Biro Administrasi Akademik dan Kemahasiswaan UIN Syarif Hidayatullah Jakarta).

Rahardjo, Mudjia. 2017. Studi Kasus dalam Penelitian Kualitatif: Konsep dan Prosedurnya, (Malang: Universitas Islam Negeri Maulana Malik Ibrahim Malang).

Rifai, Nurlena dkk., “Integrasi Keilmuan dalam Pengembangan Kurikulum di UIN Se-Indonesia: Evaluasi Penerapan Integrasi Keilmuan UIN dalam Kurikulum dan Proses Pembelajaran" Jurnal TARBIYA Vol. I, No.1, Juni 2014.

Shihab, M. Quraish. 1994. Membumikan Al-Qur'an: Fungsi dan Peran Wahyu dalam Kehidupan Masyarakat, (Bandung: Mizan).

Siregar, Prahulutun. "Integrasi Ilmu-Ilmu Keislaman dalam Perspektif M. Amin Abdullah" Jurnal MIQOT Vol. XXXVIII No. 2 Juli-Desember 2014.

\section{Website}

http://bio.fst.uinjkt.ac.id/

https://fst.uinjkt.ac.id/

fis.fst.uinjkt.ac.id

http://kim.fst.uinjkt.ac.id/ 